\title{
A Review on Symptomatology, Epidemiology and Integrated Management Strategies of Some Economically Important Fungal Diseases of Soybean (Glycine max)
}

\author{
Munmi Borah* and Bishakha Deb
}

ICAR-All India Coordinated Research Project on Soybean, Jorhat center; Department of Plant Pathology, Assam Agricultural University, Jorhat-785013, Assam, India

*Corresponding author

\section{A B S T R A C T}

\section{Keywords}

Soybean diseases, seed and seedling diseases of soybean, Rhizoctonia root rot, Pod blight, Rhizoctonia aerial blight/ web blight, Charocal rot, Rust disease and collar rot

Article Info

Accepted: 10 October 2020 Available Online: 10 November 2020
Among different production constraints in soybean, the most serious being diseases. These diseases are caused principally by fungi or bacteria however fungal diseases causing greater threat to the crop production. The damage caused by foliar diseases is mostly of minor importance except diseases like soybean rust, Pod blight, Rhizoctonia aerial blight or web blight etc. which can reduce yields when weather conditions favor disease development. Correct identification and early detection are critical in the proper management of soybean diseases. In this review we are discussing about economic importance, symptomatology, causal organism, disease cycle, epidemiology and integrated management of some economically important fungal diseases of soybean viz. Seed and seedling diseases of soybean, Rhizoctonia root rot, Pod blight, Rhizoctonia aerial blight or web blight, Charocal rot, Rust disease and collar rot.

\section{Introduction}

Soybean is valued globally for its relatively high-quality oil and protein, which comprise approximately 20 and $40 \%$ of the soybean, respectively (Clemente and Cahoon 2009). Due to high protein content, soybean is known as "poor man's meat". Seeds of soybean also contain about 33\% carbohydrates, up to $16.6 \%$ of which are soluble sugars (Hou et al., 2009). Among the grain legumes, it has the greatest potential of producing the cheapest source of food protein (Rao and Reddy, 2010). A frequent soybean protein consumption lowers the cholesterol levels and also reduces the risk of coronary heart disease (FDA, 1999; Henkel, 2000). Moreover, it improves the glucose tolerance in some diabetic patients (Messina, 1999). 
Currently, India ranks fourth in respect to production of soybean in the world. The crop helps earn valuable foreign exchange (Rs. 62000 millions in 2012-13) by way of soya meal exports. Soybean has largely been responsible in uplifting farmer's economic status in many pockets of the country. It usually fetches higher income to the farmers owing to the huge export market for soybean de-oiled cake (FICCI).

Unfortunately, soybean is susceptible to many diseases and pests that can cause significant yield losses. Although potential threats to soybean production vary by growing regions some pathogens are consistent causes for concern. Anthracnose, bacterial diseases, brown spot, charcoal rot, frog eye leaf spot, Fusarium root rot, pod and stem blight, Purple seed stain \& Cercospora leaf blight, Rhizoctonia aerial blight, Sclerotium blight, Seedling diseases, Soybean rust, Virus diseases and a few other diseases have been reported in India (Wrather et al., 2006). Another report states major biotic stresses of soybean crop in India are diseases like yellow mosaic virus, rust, rhizoctonia, anthracnose, etc., and insect pests like stem fly, gridle beetle, and various defoliators (Agarwal et al., 2013). In India, the Asian soybean rust disease was first reported on soybean in 1951 (Sharma and Mehta, 1996). Frog eye leaf spot (Cercospora sojina), rust (Phakospora pachyrhizi), powdery mildew (Microsphaera difJusa) and purple seed stain (Cercospora kikuchii) were recorded in moderate to severe form is prevalent in North Eastern Hill region (Prasad et al., 2003).

Identification followed by prevention of the diseases is the first step towards management of diseases. Increased knowledge about the location and quantity of the pathogen in relation to weather conditions provides numerous benefits to growers and researchers by providing more accurate timing of disease management. The economic impact of these diseases has spurred research on their biology, epidemiology, and management. Some of the important soybean diseases along with their epidemiology and management aspects are described in this review.

\section{Seed and seedling diseases of soybean}

Seedlings diseases have been a major constraint to Soybean (Glycine max (L.) Merr.) production in North America. From 2006 to 2009, seedling diseases ranked third among diseases and pests that reduced soybean yield in United States and Canada (Olutoyosi and Carl, 2017).

Seedling diseases of soybean (Glycine max) can be common under cool and moist soil conditions and may be caused by a complex of pathogens in North Dakota (Bradley, 2008).

\section{Symptoms}

Seed and seedling disease is caused by a complex of organisms, which mainly includes:

Phytophthora-infected seedling stems are soft and water-soaked. Overall, infected seedlings will be wilted and stunted (Crop Protection Network, 2015). At the primary leaf stage (V1), infected stems appear bruised and soft, secondary roots are rotted, the leaves turn yellow, and plants frequently wilt and die (Malvick, 2018).

Pythium- The characteristic symptom of most Pythium infections is soft, brownish-colored, rotting tissue (Malvick, 2018). Emerged plants may be killed before the first true leaf stage. These plants have a rotted appearance. Diseased plants may easily be pulled from the soil because of rotted roots (Crop Focus, 2013). 
Rhizoctonia- Infection is characterized by a shrunken, reddish-brown lesion on the hypocotyl at or near the soil line. Infection may be superficial, causing no noticeable damage, or may girdle the stem and kill or stunt plants. Causes loss of seedlings (damping-off) in small patches or within rows; is usually restricted to the seedling stage (Crop Focus, 2013).

Fusarium - Causes light- to dark-brown lesions on soybean roots that may spread over much of the root system. May attack the tap root and promote adventitious root growth near the soil surface, and may also degrade lateral roots, but usually does not cause seed rot (Crop Focus, 2013).

\section{Causal organism}

Phytophthora sojae is a fungal-like pathogen that survives in soil for up to five to 10 years in association with decomposed soybean tissues. Soybean is the only known crop host for this pathogen. It is favored by saturated, warm soil. Phytophthora sojae is an oomycete pathogen of soybean, classified in the kingdom Stramenopiles. It causes 'damping off' of seedlings and root rot of older plant

Super kingdom: Eukaryota

Kingdom: Stramenopila

Phylum: Oomycota

Class: Peronosporomycetidae

Order: Pythiales

Family: Pythiaceae

Genus: Phytophthora (Tyler, 2007).

Pythium is a soilborne, fungal-like pathogen. Several different species damage soybeans. The various species of Pythium that infect soybean have a wide host range that can include corn and many other crops. Pythium tend to be favored by cool and soil, but some species may do more damage in warm soils (Malvick, 2018)
Rhizoctonia solani is a common pathogen with a wide host range. The most common strains of this pathogen (anastamosis groups, AG) that infect soybean are AG-2-2 and AG4. AG groups can have different optimal conditions for infection.

Hyphal branch originates from distal dolipore septum with a characteristic constriction at the branching point. Conidia, clamp connections, rhizomorphs, and cultural pigmentations other than brown are never observed. Basidiomal structure of sexual state is characterized by a vertically branching hymenium succeeded by layers of elongated basidia slightly wider than basal hyphae.

Domain: Eukarya

Kingdom: Fungi

Subkingdom: Dikarya

Phylum: Basidiomycota

Subphylum: Agaricomycotina C

Class: Agaricomycetes

Order: Ceratobasidiaceae

Family: Cantharellales

Genus: Rhizoctonia (Ajayi-Oyetunde and Bradley, 2018)

Fusarium seed and seedling blight of soybean is caused by a complex of different species that may prefer different conditions. For example, some species may prefer warm and dry soils and others may prefer cool and wet soils. Some Fusarium species may also have a broad host range that includes corn and wheat (Malvick, 2018).

\section{Disease cycle}

The major stages in life cycles of most rootinfecting oomycete species of Pythium and Phytophthora are similar. The asexual cycle is characterised by the production of sporangia. Sporangia may germinate either directly in liquid or on a surface to produce a germ tube (direct germination) or may differentiate by a 
process of cytoplasmic cleavage to form uninucleate, biflagellate zoospores (indirect germination). The released zoospores swim in water in search of host tissues (seeds, roots, stems or leaves) where they settle and encyst. The cyst germinates by developing a germ tube that may penetrate the host either directly, or via an appressorium or appressorium-like structure. The sexual cycle generates thick walled oospores that are adapted for over-wintering and survival under harsh environmental conditions. Oosporogenesis involves the production of a female oogonium and a male antheridium that grows towards and fuses with the oogonium. Fertilisation occurs through the emptying of some of the contents of the antheridium into the oogonium, leading to the development of an oospore, which has a thick inner wall. This resting spore can exhibit extended dormancy and can over-winter in the soil and then germinate under suitable conditions to produce single or multiple germ tubes. These germ tubes can then form sporangia thereby recapitulating the asexual cycle of the pathogen (Van et al., 2003).

Rhizoctonia solani isolates generally do not produce vegetative or asexual spores, and the role of basidiospores as an inoculum source for the seedling diseases they incite on soybean is unknown. Its survival in the soil is aided by the formation of long-lived 'nutrientindependent propagules' called sclerotia. For most Rhizoctonia infections to occur, sclerotia must first germinate to form mycelia that grow towards the host plant (AjayiOyetunde and Bradley, 2018).

\section{Epidemiology}

General conditions that promote seed and seedling disease diseases include wet, poorlydrained, and compacted soils. However, the different pathogens have different optimal conditions. Seed and seedling diseases may be enhanced by slow germination and growth of soybeans, poor quality seed, and plant stress (Malvick, 2018).

Phytophthora root rot occurs across many environments, but is most common in warm $\left(>60^{\circ} \mathrm{F} / 15^{\circ} \mathrm{C}\right)$ and wet conditions, while Pythium Prefers cold soil temperatures $\left(<60^{\circ} \mathrm{F}\right)$. High-residue fields, and heavy or compacted soils are at higher risk because of cooler, wetter conditions (Crop Focus, 2013).

Fusarium root rot is often associated with stressed plant (Crop Protection Network, 2015).

\section{Integrated management}

Bacillus subtilis (6 g/kg), Pseudomonas fluorescens $(6 \quad \mathrm{~g} / \mathrm{kg}), \quad$ B. $\quad$ subtilis $+P$. fluorescens $(6 \mathrm{~g} / \mathrm{kg})$, Trichoderma viride (6 $\mathrm{g} / \mathrm{kg}), \quad$ T. harzianum $(6 \mathrm{~g} / \mathrm{kg})$, thiram+ carbendazim $(2 \mathrm{~g} / \mathrm{kg})$. Seed treatments with bioagents and fungicides while significantly bringing down seed borne fungi and seedling mortality both under laboratory and field conditions, enhanced seed quality, germination, vigour and yield (Rajeswari and Kumari, 2009).

Fungicide seed treatments vary in efficacy, and products that control Pythium and Phytophthora diseases (such as ethaboxam, metalaxyl (-M), and mefenoxam) do not affect Rhizoctonia and Fusarium species. Similarly, fungicides that are effective against Rhizoctonia and Fusarium have little effect on oomycetes (Crop Protection Network, 2015).

Pioneer Premium Seed Treatment helps protect against all of these stand-reducing pathogenic fungi. Pioneer offers several fungicide, insecticide and biological seed treatment choices to help meet specific local needs for stand protection. Allegiance ${ }^{\circledR}$ for 
Pythium and Phytophthora control, and 2) EverGol $^{\mathrm{TM}}$ Energy (new for 2013), a nextgeneration technology with multiple modes of action for enhanced protection against a broad spectrum of early-season disease pathogens, including Rhizoctonia, Fusarium and Pythium (Crop Focus, 2013).

\section{Pod blight disease of soybean}

Estimates of max. reductions in seed yield were 16-26\% (av. 19.7\%). Yields were typically reduced as the pods became infected in USA (Backman et al., 1982).

Estimated yield reduction of soybean (thousand metric tonnes) due to Anthracnose /Pod Blight disease in 2006 was 45.3 (Argentina), 220 (Brazil), 1663.5 (China), 117.6 (India), 0.3 (Paraguay), 492.9 (USA).

Anthracnose occurs regularly in Delhi, Uttarakhand, Himachal Pradesh, Madhya Pradesh, and Rajasthan. This pathogen can attack soybean from early seedling stage to maturity. It reduces yield by causing pod blight in various parts of India (Wrather et al., 2010).

\section{Symptoms}

Infected seeds become shriveled, mouldy and brown. Laterally the infected tissues are covered with black fruiting bodies of the fungus. Under high humidity symptoms on leaves are veinal necrosis and premature defoliation occurs (Borah, 2019).

The fungus cause anthracnose on leaves and blight on pods. Infected pods were shriveled and contain no seed (pod blanking) or more two seeded pods, with shriveled moldy seeds (Koelkar, 2017).

\section{Causal organism}

Anthracnose/Pod Blight of soybeans caused by Colletotrichum truncatum (Schwein.)
Andrus \& W.D. Moore reported as a disease of above ground parts.

Conidia were falcate, tapered towards the apex, hyaline, unicellular and aseptate, with variable dimensions, formed in the acervuli, usually produced on the top of dark brown to black stromata (Rogerio et al., 2017).

Domain: Eukaryota

Kingdom: Fungi

Phylum: Ascomycota

Subphylum: Pezizomycotina

Class: Sordariomycetes

Subclass: Sordariomycetidae

Family: Glomerellaceae

Genus: Colletotrichum

Species: Colletotrichum truncatum

\section{Disease cycle}

The life styles of Colletotrichum species can be broadly categorised as necrotrophic, hemibiotrophic, latent or quiescent and endophytic; of which hemibiotrophic is the most common (De Silva et al., 2017).

\section{Epidemiology}

Do and Paik, 1987 reported in their findings that appressoria formation of $C$. truncatum was promoted in light treatment than in dark treatment, reasonable $\mathrm{pH}$ of $\mathrm{pH} 6-\mathrm{pH} 8$.

\section{Integrated management}

Benomyl followed by carbendazim, thiram and captan were highly effective in vitro. In vivo, benomyl followed by zineb, captan and thiram gave good control. Among 7 varieties screened under artificial epiphytotic conditions, varieties JS-22 and PKV-1 were highly resistant; variety MACS-13 was also resistant (Ghawde et al., 1996). The most economical treatment found with highest $\mathrm{C}$ : B ratio (1:14.45) was the fungicide Carbendazim followed by the fungicides 
Carbendazium + Mancozeb (C:B ratio, 1:8.92) (Jagtap et al., 2012).

\section{Future approaches in disease management}

Jagtap et al., 2012 reported use of aqueous leaf extracts of garlic, tulsi and onion which inhibited $81.82 \%, 65.17 \%$ and $60.31 \%$ growth of $C$. truncatum.

\section{Rhizoctonia aerial blight /web blight of soybean}

Estimated reduction in soybean yield (thousand metric tonnes) in 2006 due to Rhizoctonia aerial blight were 300 (Brazil), 1188.2 (China), 39.2 (India), 12.5 (USA) (Wrather et al., 2010).

Aerial Blight/ web Blight of soybean caused by a fungus i.e. Rhizoctonia solani Kuhn (Teleomorph: Thanatephorus cucumeris (Frank) (donk) is a serious problem in soybean and considered to be menacing and causes heavy losses in yield particularly in warm and humid part of the country.

Aerial blight is an important disease of soybean, in USA and other soybean growing countries including India and causes substantial losses in yield. Several estimates of yield losses due to disease have been estimated. Aerial blight caused by Rhizoctonia solani is one of the most soil borne diseases of soybean particularly in the northern zone comprising the states of Haryana, Punjab, Uttar Pradesh and Uttarkhand (Kumar et al., 2016).

\section{Symptoms}

Foliar symptoms often occur during late vegetative growth stages on the lower portion of the plant following canopy closure. Initially leaf symptoms appear as watersoaked, grayish green lesions that turn tan to brown at maturity. The pathogen may infect leaves, pods, and stems in the lower canopy. Reddish-brown lesions can form on infected petioles, stems, pods and petiole scars. Long strands of web-like hyphae can spread along affected tissue and small (1/16 to 3/16 in. in diameter), dark brown sclerotia form on diseased tissue (Faske and Kirkpatrick, n.d.).

\section{Causal organism}

The anamorph or imperfect stage of pathogen causing aerial blight in soybean is Rhizoctonia solani Kühn.

Domain Eukarya

Kingdom Fungi

Subkingdom Dikarya

Phylum Basidiomycota

Subphylum Agaricomycotina C

Class Agaricomycetes

Order Ceratobasidiaceae

Family Cantharellales

Genus Rhizoctonia

Species: $R$. solani

$R$. solani include septate hyphae, multinucleate cells in young hyphae, brown colouration of mature hyphae, right-angled hyphal branching, constriction at the point of branching, dolipore septa that permits unrestricted cell-to-cell movement of cytoplasm, mitochondria and nuclei, production of monilioid cells, and sclerotia of uniform texture (Ajayi-Oyetunde and Bradley, 2018).

\section{Disease cycle}

Rhizoctonia solani isolates generally do not produce vegetative or asexual spores, and the role of basidiospores as an inoculum source for the seedling diseases they incite on soybean is unknown. Its survival in the soil is aided by the formation of long-lived 'nutrientindependent propagules' called sclerotia. For 
most Rhizoctonia infections to occur, sclerotia must first germinate to form mycelia that grow towards the host plant (AjayiOyetunde and Bradley, 2018).

\section{Epidemiology}

The epidemiology of aerial blight may be divided into two phases, one before and one after canopy closure. The first phase is soil borne and determines the number of potential disease foci in the crop canopy. The second phase is leaf borne and is important to the expansion of disease foci. During the growing season, patterns of rainfall between the two phases are an important determinant of the development of aerial blight (Yang et al., 1990).

High soil moisture (80\%) and 25 OC temperature were the most favourable for root rot development while web blight was best favoured at $>85 \%$ relative humidity coupled with 25 0C temperature. Continuous leaf wetness for at least $6 \mathrm{hrs}$ was essential for disease initiation, while increase in leaf wetness duration for 6-12 hrs showed corresponding disease incubation period observed with further increase in leaf wetness (Kumar et al., 2016).

\section{Integrated management}

The use of resistant varieties is the cheapest, easiest, safest and most effective method to manage the aerial blight disease. The efforts through conventional breeding so far made in developing commercial cultivars resistant to aerial blight (Kumar et al., 2016).

Rotate with poor or non-host crops such as corn or grain sorghum for two-years and avoid narrow row widths and high plant populations are good management practices (Faske and Kirkpatrick).
Simulations from a soyabean growth model (SOYGRO) indicated that higher yields could be expected with wider row spacings during drought years (Joye et al., 1990).

\section{Charcoal rot of soybean}

Charcoal rot was most severe in the dry areas of Argentina, Bolivia, Brazil, India, Paraguay, and the United States. Estimated reduction of soybean yields (thousand metric tonnes) due to Charcoal rot in 2006 were 905 (Argentina), 500 (Bolivia), 360 (Brazil), 1.6 (Canada), 39.2 (India), 1.6 (Paraguay), 697.6 (USA) (Wrather et al., 2010).

In India Charcoal rot was one of the diseases of Soybean causing most yield losses in 2006. Charcoal rot has accounted for more yield loss in India since 2004 due to erratic rainfall and greater periods of drought. It has caused the most damage to soybean in the major soybean states of Madhya Pradesh, Maharashtra, Rajasthan, and Karnataka. Yield losses have been as high as $77 \%$ in some fields (Wrather et al., 2010). The charcoal rot, which is used to be a minor disease of soybean until 2004 in India, became a serious pest due to altered weather conditions particularly on the account of longer drought spells during crop growth period (Gupta et al., 2012).

\section{Symptoms}

On seedlings, after emergence, symptoms can be visible on cotyledons as brown to dark spots. Sometimes, the margins of the cotyledons become brown to black and shed at an early stage. From the unifoliate leaf stage onwards, the symptoms appear on emerging hypocotyls of infected seedlings as circular to oblong, reddish-brown, lesions that may turn dark brown to black after several days. These lesions may extend up the stem. Infected seedlings may die if hot and dry 
conditions persist. The pathogen causes lesions on the roots, stems, pods and seeds. Foliar symptoms progress from top of the plant downwards. Leaves of infected plants remain smaller than normal and subsequently turn yellow prior to wilting.

A reddish-brown discolouration of the vascular elements of roots and lower stem precedes the premature yellowing as the fungus spreads up the stem during the season. The infected mature and dry pods are covered with locally or widely distributed black bodies (microsclerotia).

After the death of the plant, numerous, minute, pinhead-sized microsclerotia appear, which can be seen readily when the epidermal tissue of the lower stems and roots is peeled from the affected parts. The infected crop in the field exhibits premature yellowing in scattered patches (Gupta et al., 2012).

\section{Causal organism}

Macrophomina phaseolina is a soil inhabiting organism capable of infecting soybean at any crop growth stage, but usually, it infects at post flowering stage. The fungus is also seedborne in many crops including soybean. It produces microsclerotia in root and stem tissues of host plants, which enable it to survive in soil for 2-15 years and act as primary source of inoculum. The pycnidiospores in Macrophomina are ellipsoid to obovoid and measure 20-24 · 7-9 $\mu \mathrm{m}$ (Gupta et al., 2012).

Domain: Eukaryota

Kingdom: Fungi

PhySubphylum: Pezizomycotina

Class: Dothideomycetes

Order: Botryosphaeriales

Family: Botryosphaeriaceae

Genus: Macrophomina

Species: Macrophominaphaseolina

\section{Disease cycle}

The pathogen mainly produces either microsclerotia (primary source of inoculum) or pycnidia. The pathogen life cycle begins with microsclerotia germination into the soil. Under favorable environmental conditions (low water potential and high soil temperature) and in the presence of the host plants, microsclerotia germinate and produce a mass of hyphal threads. The hyphae grow towards the host's roots and colonize the seedlings roots during the first weeks of seed germination. When plants approach the end of the growing season and pathogen enters into its necrotrophic phase, plants show symptoms like wilting and necrosis due to blockage of vascular bundles with microsclerotia, enzymes activity and secretion of pathogenic toxins. The most diagnostic symptom of charcoal rot in invaded soybean plants is the black and dusty speckled appearance of microsclerotia on stems, pods and seeds as well as interior tissues like vascular, cortical, and pith tissues (Hemmati et al., 2018).

\section{Epidemiology}

Meyer et al., 1974 in his findings found that disease was greatest at $30-35^{\circ} \mathrm{C}$, although some infections occurred on soybean seedlings at $20-25^{\circ} \mathrm{C}$. Infected seedlings may serve as a latent source of inoculum of the mature plant phase over a wide temperature range. With increase in number of viable $M$. phaseolina propagules, the disease seedlings also increased.

Seedlings can be infected in years when soils are exceptionally dry and soil temperatures are continuously above $35 \mathrm{C}$ for 2-3 weeks. The germination of microsclerotia in soybean fields is favoured by dry soils, high soil C: $\mathrm{N}$ ratios of amendments, low bulk density (Gupta et al., 2012). 
Fig.1 (A)-(B) Soybean seeds infected by Pythium sp. Image: Borah, 2019; (C) cotyledons affected by Phytophthora root Rot Image: Borah, 2019; (D)-(E) Seedlings affected by Rhizoctonia root Rot Image: Borah, 2019; (F) Seedlings affected by by Fusariumsp Image: Borah, 2019.; (G) Disease cycle of Phytophthora sp. and Pythium sp.Van et al., 2003; (H) Disease cycle of Rhizoctonia solani' Image: Ajayi-Oyetunde and Bradley 2018; (I) Disease cycle of Fusarium Image: Dweba et al., 2017
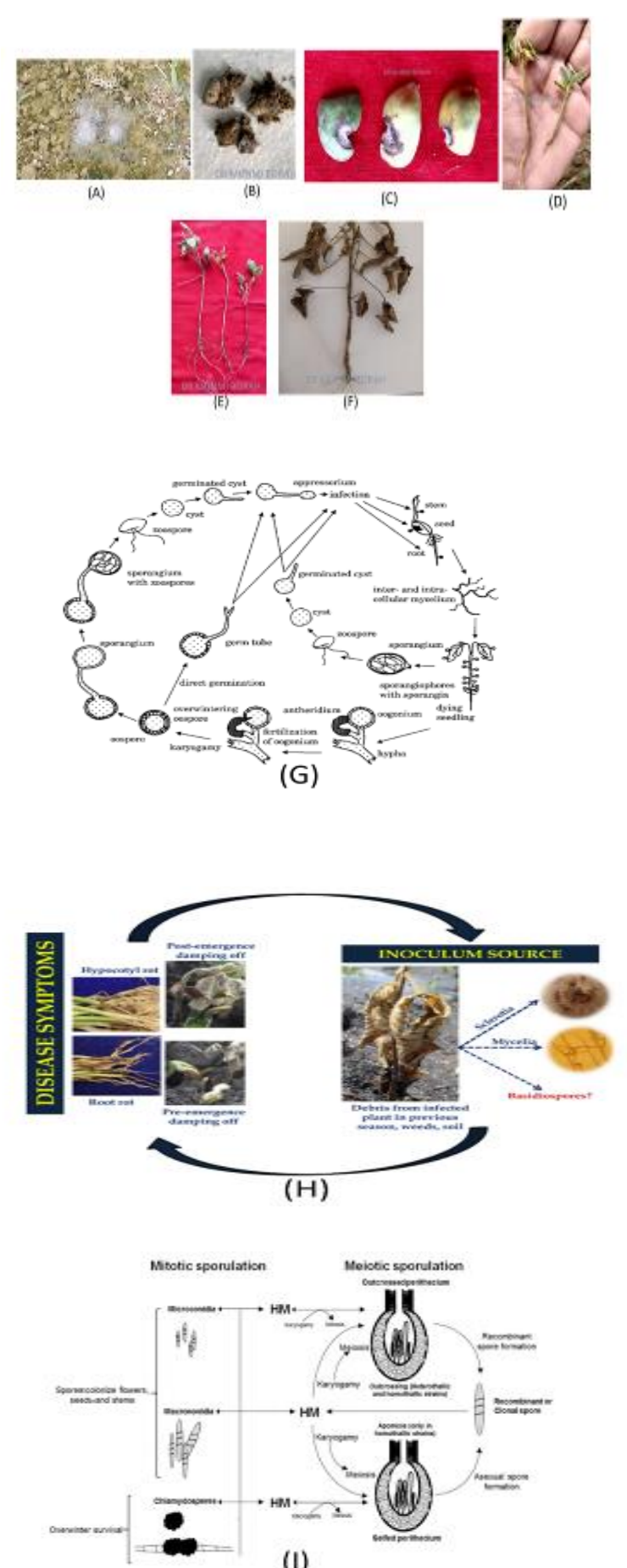

(1) 
Fig.2 (A)Symptoms on Cotyledons; Image; Kolekar, 2017; (B) Symptoms on leaf, Image ; Kolekar, 2017; (C) Symptoms on pods; Image; Kolekar, 2017.; (D) Disease cycle of Colletotrichum

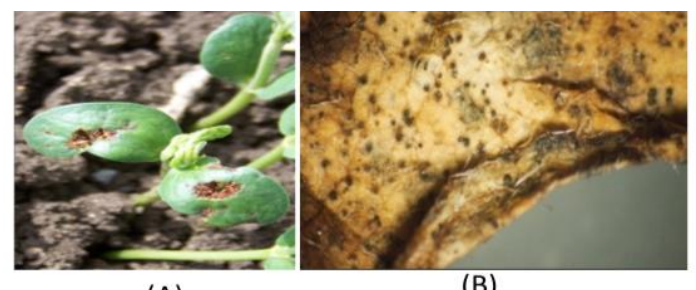

(A)

(B)
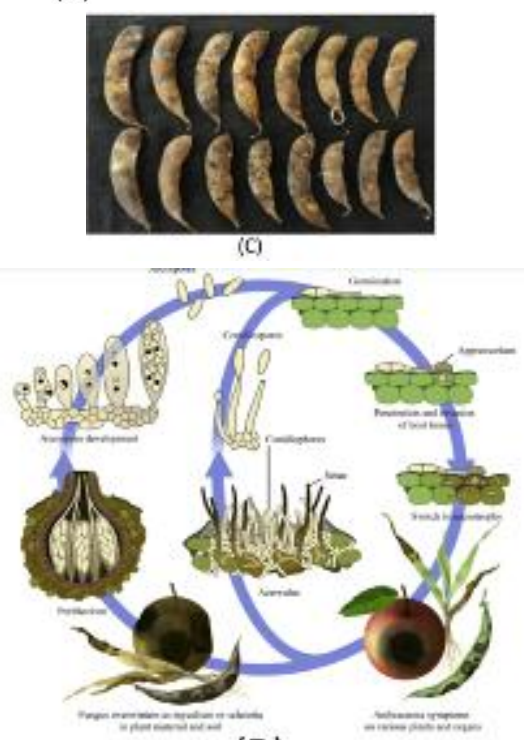

(D)

Fig.3 (A) Web-like hyphae of Rhizoctonia solani spreading along the stem of soybean Image: Faske and Kirkpatrick, n.d.; (B) Water soaked, greenish lesions Image: Faske and Kirkpatrick, n.d.; (C) Mature sclerotia of Rhizoctonia solani on soybean petiole Image: Faske and Kirkpatrick, n.d.; (D) Disease cycle of Rhizoctonia solani Image: Ajayi-Oyetunde and Bradley, 2018

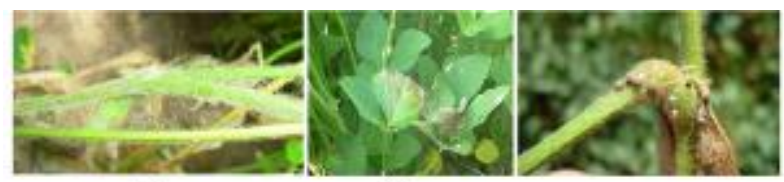

(A)

(B)

(C)

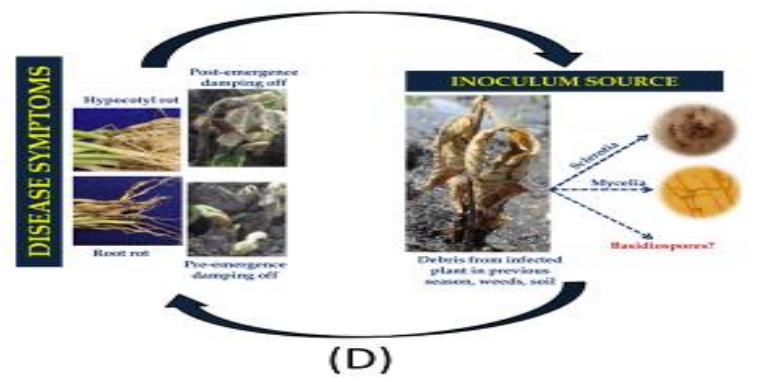


Fig.4 (A) Stunted / wilted plants Image : Crop Protection Network; (B) A reddish-brown discolouration of the vascular elements of roots and lower stem;(C) Disease cycle of Macrophomina phaseolina Image Hemmati et al., 2018

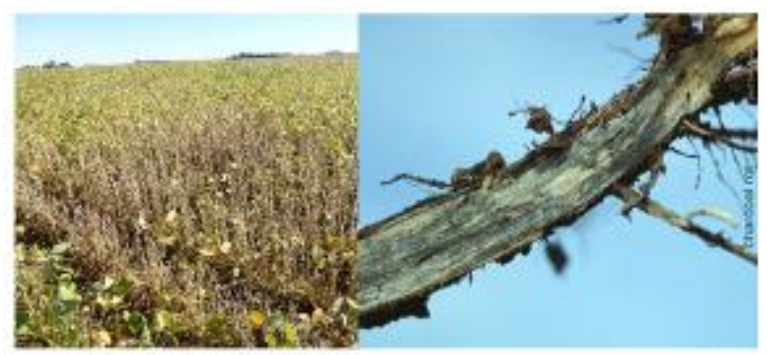

(A)

(B)

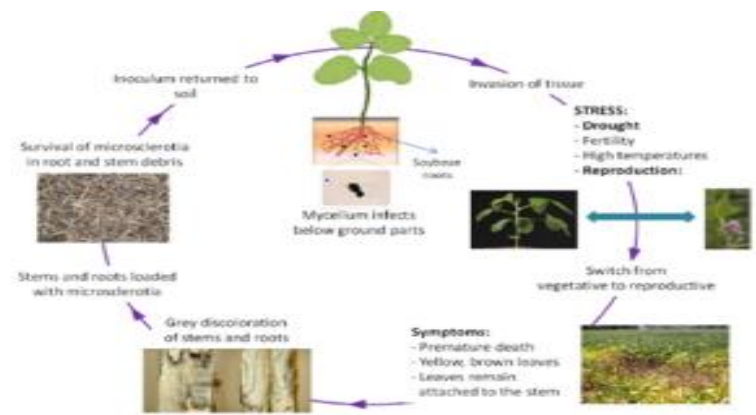

(C)

Fig.5 (A)-(B) Symptom of rust on Soybean leaf Image: Rupe and Sconyers, 2008; (C) Disease cycle of Phakopsora pachyrhiz; Image: Goellner et al., 2010)

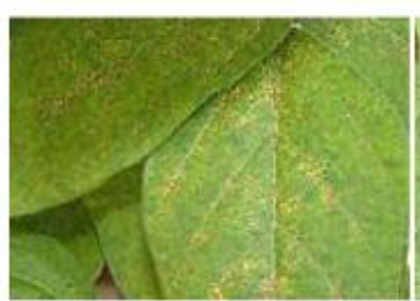

(A)

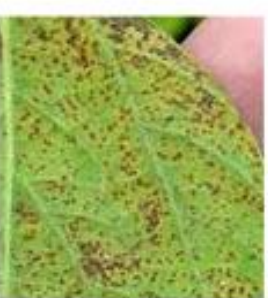

(B)

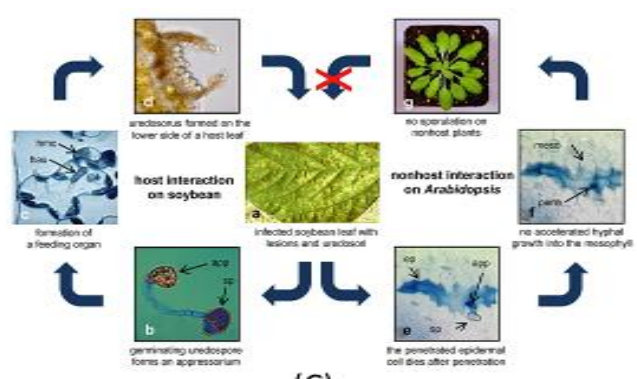

(C) 
Fig.6 Collar rot of soybean showing sclerotia at the collar region of the plant Image: Borah, 2019

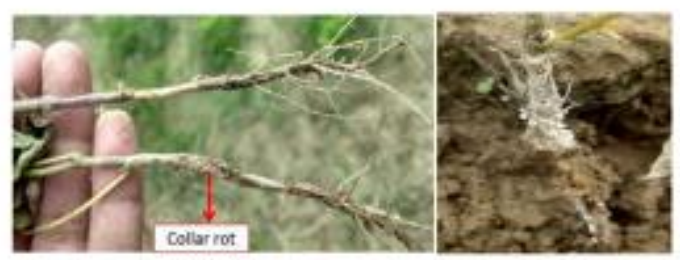

(A)

(B)

Fig.7 (A) Young plants killed by R. solani Image: Malvick, 2018'; (B) Rhizoctonia root and stem rot Image: Malvick, 2018; (C) Disease cycle of Rhizoctonia solani,

Image: Ajayi-Oyetunde and Bradley, 2018

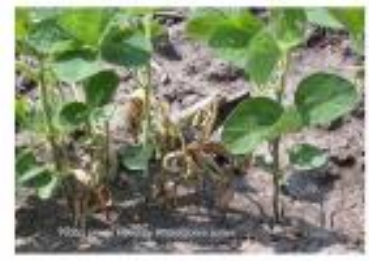

(A)

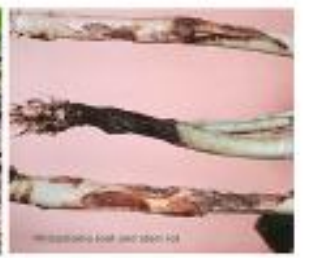

(B)

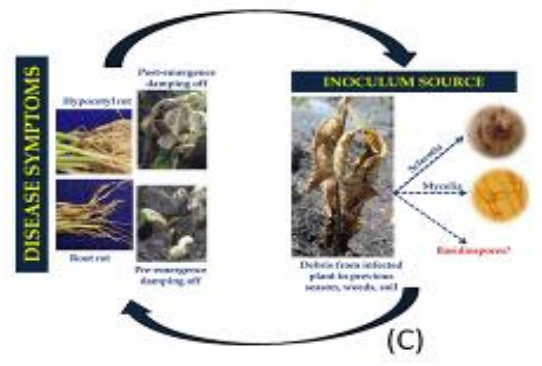

\section{Integrated management}

Charcoal rot disease can be controlled by organic amendments such as farmyard manure, neem and mustard cake (Rathore, 2000; Gupta et al., 2012).

Soil fumigation with sodium methyldithio carbamate reduced populations of the pathogen on soybean residue and in the roots of plants grown in field plots (Kittle and Gray, 1982; Gupta et al., 2012).

Seed treatment with captan at $3 \mathrm{~g} / \mathrm{kg}$ or thiram at $3 \mathrm{~g} k \mathrm{~kg}$ or thiram + carbendazim (2:1) at 3 $\mathrm{g} k \mathrm{~kg}$ or thiram + carboxin at $2 \mathrm{~g} k \mathrm{~kg}$ seed (Gupta and Chauhan, 2005; Gupta et al., 2012).

In India, use of $T$. viride or Trichoderma harzianum as a seed treatment (4-5 g $k \mathrm{~kg}$ seed) has been recommended for the management of charcoal rot in soybean (Gupta and Chauhan 2005). Seed treatment with Pseudomonas aeruginosa reduced infection of $M$. phaseolina by $14-100 \%$, depending on the strain of bacterium and the variety of soybean used (Ehteshamul-Haque et al., 2007; Gupta et al., 2012). 
Seed infection of $M$. phaseolina was completely inhibited by dipping the seeds for 5 min in ginger, garlic and neem extracts (Hossain et al., 1999; Gupta et al., 2012).

\section{Future approaches in disease management}

The role of RNA interference (RNAi) in the development of disease-resistant varieties and further suggested that such goal can be achieved in a more selective and robust manner with the success of genetic engineering techniques. In this regard, RNAi has emerged as a powerful tool to overcome the threats posed by viruses, fungi and bacteria.

Possibilities may be explored to utilize RNA mediated gene silencing technology like RNAi by supreesing the specific gene(s) governing susceptibility to charcoal rot in soybean for successful management of the disease (Wani et al., 2010; Gupta et al., 2012).

\section{Rust disease of soybean}

Soybean rust caused by $P$. pachyrhizi has been a serious disease in Asia for many decades. It appeared in Africa in 1997, and in the Americas in 2001 (Rupe and Sconyers, 2008).

Soybean rust is one of the worst soybean diseases in India and may reduce yields up to $100 \%$ depending on the time of infection, variety planted, and climate. Initially, soybean rust was restricted to the northeastern states of India and the hills of Uttar Pradesh and West Bengal prior to 1977 and caused little loss of soybean yield. Around 1993, it spread to other areas such as Madhya Pradesh, Maharashtra, Rajasthan, Karnataka, Andhra Pradesh, Himachal Pradesh, Tamil Nadu, and Kerala. It usually develops in India from the third week of July to the last week of September. This pathogen survives on volunteer and wintersown soybean in southern India and then spreads to soybean in more northern areas during the rainy season.

The estimated reduction of yield in 2006 due to Soybean Rust in different countries are reported to be 45.3 (Argentina), 2000(Bolivia), 4720(Brazil), 6368.9(China), 78.4(India), 1.9(Paraguay), 24.59 (USA) in thousand metric tonnes (Wrather et al., 2010).

\section{Symptoms}

The first symptoms of soybean rust caused by Phakopsora pachyrhizi begin as very small brown or brick-red spots on leaves. Often the first lesions appear toward the base of the leaflet near the petiole and leaf veins. This part of the leaflet probably retains dew longer, making conditions more favorable for infection. Lesions remain small $(2-5 \mathrm{~mm}$ in diameter), but increase in number as the disease progresses. Pustules, called uredinia, form in these lesions, mostly on the lower leaf surface, and they can produce many urediniospores. Soybean rust urediniospores are pale yellow-brown to colorless, with an echinulate (short spines) surface ornamentation. As more and more lesions form on a leaflet, the affected area begins to yellow, and eventually the leaflet falls from the plant. Yield losses as high as 30 to $80 \%$ have been reported, but the amount of loss depends on when the disease begins and how rapidly it progresses. Besides leaves, soybean rust can also appear on petioles, stems, and even cotyledons, but most rust lesions occur on leaves (Rupe and Sconyers, 2008).

\section{Causal organism}

The plant pathogenic basidiomycete fungi Phakopsora pachyrhizi and Phakopsora meibomiae cause rust disease in soybean plants. Phakopsora pachyrhizi originated in 
Asia-Australia, whereas the less aggressive $P$. meibomiae originated in Latin America

Domain Eukaryota;

Kingdom Fungi;

Phylum Basidiomycota;

Order Uredinales;

Class Urediniomycetes;

Family Phakopsoraceae;

Genus Phakopsora (Goellner et al., 2010).

\section{Disease cycle}

Interaction of $P$. pachyrhizi with its host soybean and the nonhost plant Arabidopsis. a) Upon infection $P$. pachyrhizi forms uredia which are located mainly on the lower side of the leaf. Newly formed uredospores are dispersed by wind. b) Spores landing on leaves germinate and form an appressoria as depicted in the interference contrast micrograph. c) Intercellular hyphae form haustorial mother cells (hmc) from which haustoria (hau) develop inside mesophyll cells. d) The life cycle of $P$. pachyrhizi is completed with the formation of uredospores in uredia. e) In the nonhost interaction between the fungus and Arabidopsis uredospores germinate, form appressoria and penetrate epidermal cells as known from the host type of interaction.

Similarly penetrated epidermal cells of host and nonhost plants die, as indicated after trypan-blue staining. f) Fungal growth is restricted at the mesophyll boundary. Pictures shown in e and $f$ are optical sections from the same infection site focused either on the epidermal or mesophyll layer. g) $P$. pachyrhizi is unable to complete its life cycle and does not sporulate on wild-type Arabidopsis plants. sp, uredospore; app, appressorium; epi, epidermal cell; hau, haustorium; hmc, haustorial mother cell; penh, penetration hypha; meso, mesophyll cell (Koch et al., 1983; Goellner et al., 2010).

\section{Epidemiology}

The temperature in the range of $15-25^{\circ} \mathrm{C}$ in the presence of free moisture on the leaf surface is essential for the germination of uredospore. The maximum infection was found at $20-25^{\circ} \mathrm{C}$ with $10-12$ hours dew period (Sharma and Gupta, 2006).

Generally, infection occurs when leaves are wet and temperatures are between $8^{\circ} \mathrm{C}$ and $28^{\circ} \mathrm{C}$, with an optimum of $16^{\circ} \mathrm{C}$ to $28^{\circ} \mathrm{C}$. At $25^{\circ} \mathrm{C}$, some infection occurs in as little as 6 hours of leaf wetness, but 12 hours are optimal. After infection, lesions and pustules with urediniospores can appear within 7 or 8 days, and the next infection cycle is set to begin. Besides the environment, plant age affects soybean rust epidemics.

Usually, rust lesions are not found on soybean until flowering, unless there are high inoculum levels early in the season. This may be due to greater susceptibility of plants to rust as the host enters the reproductive stages, it may be because in lower parts of the canopy spores are more protected from UV radiation, or it may be because conditions in the canopy become more humid as the canopy closes. In any event, lesions can form at any growth stage, but major increases in disease do not occur until after flowering (Rupe and Sconyers, 2008).

\section{Integrated management}

There are three basic management tactics that can play a role in reducing soybean rust epidemics: fungicides, genetic resistance, and cultural practices. At present, fungicides are the only highly effective tactic, but long-term management will probably depend more on resistance, in combination with fungicides and changes in cultural practices (Rupe and Sconyers, 2008). 


\section{Future approaches in disease management}

Joint combination of systemic and multisite fungicides uses and genotypes with partial resistance, this strategy might be promising in future (Juliatti et al., 2017).

Biotechnological approaches like non host resistance, gene silencing are the other future approaches for disease management (Godoy et al., 2016).

\section{Collar rot disease of soybean}

Root rot and collar rot are the important diseases of soybean, in Vidarbha region of Maharashtra (Khodke and Raut, 2010).

Collar rot of soybean caused by Sdewthimrolfsii, has attained the major status in many soybean cultivating areas of northern Karnataka. Survey conducted in ten taluks of northern Karnataka during kharif 2002-03 indicated maximum disease incidence of 9.80\% in Dharwad and traces in Bidar and Athani taluks (Prabhu, 2003).

\section{Symptoms}

Infection occurs at or just below the soil surface. Yellowing or wilting of plants is the first symptom. Leaves turn brown, dry and often cling to dead stem. Numerous tan to brown spherical sclerotia form on infected plant material (Borah, 2019).

\section{Causal organism}

Collar rot caused by Sclerotium rofsii Sacc. (Anamorph) appears during seedling stage

Domain: Eukaryota

Kingdom: Fungi

Phylum: Basidiomycota

Subphylum: Agaricomycotina

Class: Agaricomycetes
Subclass: Agaricomycetidae

Order: Polyporales

Family: Atheliaceae

Genus: Athelia

Species: Atheliarolfsii (Teleomorph)

At least two types of hyphae are produced. Coarse, straight, large cells (2-9um x 150250um) have two clamp connections at each septation, but may exhibit branching in place of one of the clamps. Branching is common in the slender hyphae (1.5-2.5um in diameter) which tend to grow irregularly and lack clamp connections. Slender hyphae are often observed penetrating the substrate.

Sclerotia $(0.5-2.0 \mathrm{~mm}$ diameter $)$ begin to develop after 4-7 days of mycelial growth. Initially a felty white appearance, sclerotia quickly melanize to a dark brown coloration (Fichtner, n.d.).

\section{Disease cycle}

When the cottony growth of the fungus comes into contact with susceptible roots, leaves or stems, direct penetration occurs, but the fungus can also infect through wounds. It produces chemicals that cause soft rots in 2-4 days after infection. When the soft rots girdle the stem, the foliage wilts and death of the plant follows soon after.

The fungal growth can easily be seen with the naked eye. About 7 days after infection, the cottony growth begins to form sclerotia. These are 0.5-2 $\mathrm{mm}$ diameter and made up of tightly packed strands of the fungus. They are white becoming light brown as they mature. Sclerotia keep the fungus alive when there are no plants to infect. They remain alive for several years in soil or potting mix. Other than sclerotia, the fungus can survive between crops in the remains of plants. The life cycle is given below (Pestnet, n.d.). 


\section{Epidemiology}

Sclerotia serve as the principle overwintering structures and primary inoculum for disease. Persisting near the soil surface, sclerotia may exist free in the soil or in association with plant debris. Those buried deep in the soil may survive for a year or less, whereas those at the surface remain viable and may germinate in response to alcohols and other volatiles released from decomposing plant material. Thus, deep plowing serves as a cultural control tactic by burying sclerotia deep in the soil. High temperatures and moist conditions are associated with germination of sclerotia. High soil moisture, dense planting, and frequent irrigation promote infection (Fichtner, n.d.).

\section{Integrated management}

Deep ploughing in summer, crop rotation with maize or sorghum, Destroy infected stubble (Kisan Suvidha).

Belkar and Gade, 2013 reported that seed treatment with Pseudomonas fluorescens @ $10 \mathrm{~g} / \mathrm{kg}$ of seed + Bradyrhizobium japonicum @ 20g/kg of seed + Pseudomonas striata @ $20 \mathrm{~g} / \mathrm{kg}$ of seed was effective with minimum disease incidence i.e. 8.86\%, 13.33\%, 20.00\% at 20 DAS and $17.73 \%, 33.33 \%$ and $40.00 \%$ at flowering, respectively.

Ansari, 2005 reported that from seed treatment with Trichoderma viride at $4 \mathrm{~g} / \mathrm{kg}$, Pseudomonas fluorescens at $10 \mathrm{~g} / \mathrm{kg}$, recommended chemicals thiram+carbendazim $(2: 1)$ at $3 \mathrm{~g} / \mathrm{kg}$, and an untreated control, Treatment with biological control agents produced more sturdy and vigorous plants than those treated with chemicals and untreated control.

Seed treatment and soil application of fungicides, bioagents and its combinations were found effective in increasing seed germination and reducing pre and post emergence mortality. Maximum germination was achieved due to seed treatment with treatment T7 (Thiram+Carbendazim + Trichoderma @ 3+1+4 g/kg) i.e. 89.15, 81.33 and 83.14 per cent in consecutive three years followed by seed treatment with Thiram + Carbendazim 3+1 g/kg (T-6) (Khodke and Raut, 2010).

\section{Rhizoctonia root rot of soybean}

Economic importance of the disease (in India and abroad)

Rhizoctonia root and hypocotyl rot, caused by Rhizoctonia solani Kuhn [teleomorph Thanatephorus cucumeris (Frank) Donk], is an important disease of soybean [Glycine max (L.) Merr.] (Zhao et al., 2005).

Rhizoctonia root and stem rot is a common soybean disease that typically causes most damage to seedlings, but can also damage older plants. It can kill and stunt plants to result in significant yield losses, or the lesions can be superficial and have minimal effects on plant health. Rhizoctonia is a fungal pathogen that infects many different plants in the northern U.S., but only some types of this pathogen infect soybean (Malvick, 2018).

\section{Symptoms}

Rusty-brown, dry sunken lesions on stems and roots near the soil line are a characteristic symptom of Rhizoctonia infection. Lateral roots may be decayed.

Seedlings or older plants may develop these infections and become stunted, yellow, and may wilt. The infections can be superficial and cause no clear damage to plants, or they can girdle the stem and kill or stunt plants (Malvick, 2018). 


\section{Causal organism}

Rhizoctonia solani (a soilborne fungus). This fungus has a wide host range that may include soybean, corn, alfalfa, and other crops; but only some types of this pathogen infect soybean. The most common strains of this pathogen (anastamosis groups also referred to as 'AG') that infect soybean are AG-2-2 and AG-4. Different AG groups can have different optimal conditions for growth and infection (Malvick, 2018).

Hyphal branch originates from distal dolipore septum with a characteristic constriction at the branching point. Conidia, clamp connections, rhizomorphs, and cultural pigmentations other than brown are never observed. Basidiomal structure of sexual state is characterized by a vertically branching hymenium succeeded by layers of elongated basidia slightly wider than basal hyphae.

Domain Eukarya

Kingdom Fungi

Subkingdom Dikarya

Phylum Basidiomycota

Subphylum Agaricomycotina C

Class Agaricomycetes

Order Ceratobasidiaceae

Family Cantharellales

Genus Rhizoctonia (Ajayi-Oyetunde and Bradley, 2018)

\section{Disease cycle}

Rhizoctonia solani isolates generally do not produce vegetative or asexual spores, and the role of basidiospores as an inoculum source for the seedling diseases they incite on soybean is unknown. Its survival in the soil is aided by the formation of long-lived 'nutrientindependent propagules' called sclerotia. For most Rhizoctonia infections to occur, sclerotia must first germinate to form mycelia that grow towards the host plant (AjayiOyetunde and Bradley,2018).

\section{Epidemiology}

Rhizoctonia root and stem rot occurs primarily in early to mid summer. Infected plants typically appear in patches in a row or field. Several different conditions can favor this disease including, high soil moisture, warm soil temperatures, soil types with high amounts of organic matter, and delayed emergence. Plant stress from herbicide or hail injury or the soybean cyst nematode (SCN) also may favor this disease (Malvick, 2018).

\section{Integrated management}

Planting resistant cultivars would be an effective and environmentally sound strategy to minimize economic losses from this disease (Zhao et al., 2005).

Encourage seedling health with good agronomic practices and the use of high quality seed. Avoid or reduce plant stress, for example from herbicide injury and SCN infection. Crop rotation and tillage may be of value where disease has been severe. Some seed treatment fungicides may reduce Rhizoctonia infection for a few weeks after planting. Soybean cultivars may have different levels of tolerance, but none are fully resistant to this disease (Malvick, 2018).

In conclusion: the correct identification and early detection are critical in the proper management of soybean diseases. We have discussed about economic importance, symptomatology, causal organism, disease cycle, epidemiology and integrated management of some economically important fungal diseases of soybean viz. seed and seedling diseases of soybean, Pod blight, Rhizoctonia aerial blight or web blight, Charocal rot, Rust disease, collar rot and Rhizoctonia root rot disease of soybean. Seed and seedling diseases of soybean are more prevalent when wet season follows planting. 
The disease can cause economic loss due to weak and less vigorous plants leading to poor crop stand establishment. Rhizoctonia aerial blight disease can cause significant yield loss in soybean when conditions favor disease development. The charcoal rot disease is more severe when plants are under stress from moisture or nutrients, excessive plant densities, soil compaction, improperly applied pesticides, nematodes or other pathogens. Although good progress in research on charcoal rot in soybean has been made during the past decade, still systematic studies are required to bridge the gap in knowledge of physiological variability and pathogenicity. Rust fungi, being a biotrphic pathogen, requires integrated management approach, owing to its high yield loss. If host is available, it can occur all the year round and it occurs in major soybean producing regions of the world. The fungus Colletotrichum truncatum (Schwein.) causing pod blight causing severe economic loss as pods get heavily infested, which requires an integrated management approach. Rhizoctonia bataticola and Sclerotium rolfsii causes root rot and collar rot in Soybean and is considered as economically important diseases of Soybean.

\section{References}

Agarwal, D. K., Billore, S. D., Sharma, A. N., Dupare, B. U., and Srivastava, S. K. (2013). Soybean: introduction, improvement, and utilization in Indiaproblems and prospects. Agricultural Research, 2(4), 293-300.

Ajayi-Oyetunde, O. O., and Bradley, C. A. (2018). Rhizoctonia solani: taxonomy, population biology and management of rhizoctonia seedling disease of soybean. Plant pathology, 67(1), 3-17.

Ansari, M. M. (2005). Management of collar rot of soybean through biological agents. Plant Disease Research
(Ludhiana), 20(2), 171-173.

Backman, P. A., Williams, J. C., and Crawford, M. A. (1982). Yield losses in soybeans from anthracnose caused by Colletotrichum truncatum. Plant Disease, 66(11), 1032-1034.

Belkar, Y. K., \&Gade, R. M. (2013). Management of root rot and collar rot of soybean by antagonistic microorganism. Journal of Plant Disease Sciences, 8(1), 39-42.

Borah, M. (2019). Identification of Soybean Diseases In Assam. Int $J$ Recent Sci Res. 10(08), pp. 34154-

34159. DOI: http://dx.doi.org/ 10.24327/ijrsr.2019.1008.3832

Bradley, C. A. (2008). Effect of fungicide seed treatments on stand establishment, seedling disease, and yield of soybean in North Dakota. Plant Disease, 92(1), 120-125.

Clemente, T. E., and Cahoon, E. B. (2009). Soybean oil: genetic approaches for modification of functionality and total content. Plant physiology, 151(3), 1030-1040.

Crop Focus. (2013). Soybean Seed and Seedling Diseases. Retrieved from http://www.compassagservices.com/wp

content/uploads/2015/05/ais228_Crop_ Focus_Soybean_Seedling_Diseases.pdf

Crop Protection Network. (2015). Soybean Disease Management. Retrieved from https://soybeanresearchinfo.com/pdf_do cs/Soybean_Seedling_Diseases_CPN10 08.pdf

De Silva, D. D., Crous, P. W., Ades, P. K., Hyde, K. D., and Taylor, P. W. (2017). Life styles of Colletotrichum species and implications for plant biosecurity. Fungal Biology Reviews, 31(3), 155168.

Do, E. S., and Paik, S. B. (1987). Effect of Environmental Factors on Appressorium Formation of 
Colletotrichum truncatum. The Korean Journal of Mycology, 15(3), 142-148.

Dweba, C. C., Figlan, S., Shimelis, H. A., Motaung, T. E., Sydenham, S., Mwadzingeni, L., and Tsilo, T. J. (2017). Fusarium head blight of wheat: Pathogenesis and control strategies. Crop Protection, 91, 114-122.

Ehteshamul-Haque, S., Sultana, V., Ara, J., Athar, M. (2007) Cultivar response against root-infecting fungi and efficacy of Pseudomonas aeruginosain controlling soybean root rot. Plant Biosyst 141: 51-55.

Faske, T. and Kirkpatrick, T. (n.d). Aerial Blight of Soybean . Retrieved from https://www.uaex.edu/farmranch/crops-commercialhorticulture/docs/Faske\%209\%20Aerial \%20Blight.pdf

FICCI. (n.d). Evaluation of the PPPIAD Project on Soybean. Retrieved from http://ficci.in/spdocument/20539/SOYB EAN-Report.pdf

Fichtner, E.J. (n.d). Sclerotium rolfsii Sacc. : 'Kudzu of the Fungal World'. Retrieved from https://projects.ncsu.edu/cals/ course/pp728/Sclerotium/Srolfsii.html

Food and Drug Administration (FDA). 1999. FDA approves new health claim for soybean protein and coronary heart disease. FDA Talk Paper, in www.fda.gov.G. (ed.) The Soybean: Botany, Production and Uses.

Ghawde, R. S., Gaikwad, S. J., and Borkar, S. L. (1996). Evaluation of fungicides and screening of varieties against pod blight of soybean caused by Colletotrichum truncatum (Schewein) Andrus and Moore. Journal of Soils and Crops, 6(1), 97-99.

Godoy, C. V., Seixas, C. D. S., Soares, R. M., Marcelino-Guimarães, F. C., Meyer, M. C., and Costamilan, L. M. (2016). Asian soybean rust in Brazil: past, present, and future. Pesquisa
Agropecuária Brasileira, 51(5), 407421.

Goellner, K., Loehrer, M., Langenbach, C., Conrath, U. W. E., Koch, E., \& Schaffrath, U. (2010). Phakopsorapachyrhizi, the causal agent of Asian soybean rust. Molecular plant pathology, 11(2), 169-177.

Gupta, G.K. and Chauhan, G.S. (2005) Symptoms, Identification and Management of Soybean Diseases. Technical Bulletin 10. Indore, India, National Research Centre for Soybean

Gupta, G. K., Sharma, S. K., and Ramteke, R. (2012). Biology, epidemiology and management of the pathogenic fungus Macrophomina phaseolina (Tassi) Goid with special reference to charcoal rot of soybean (Glycine max (L.) Merrill). Journal of Phytopathology, 160(4), $167-180$.

Hemmati, P., Zafari, D., Mahmoodi, S. B., Hashemi, M., Gholamhoseini, M., Dolatabadian, A., and Ataei, R. (2018). Histopathology of charcoal rot disease (Macrophomina phaseolina) in resistant and susceptible cultivars of soybean. Rhizosphere, 7, 27-34.

Henkel J. (2000). Soybean: Health claims for soybean protein, questions about other components. FDA Consumer, in www.cfsan.fda.gov

Hossain, I., Suratuzzaman, M., Khalil, M.I. (1999) Seed health of soybean and control of seed borne fungi with botanicals. Bangladesh $\mathrm{J}$ Train Dev 12:99-105.

Hou, A., Chen, P., Alloatti, J., Li, D., Mozzoni, L., Zhang, B., and Shi, A. (2009). Genetic variability of seed sugar content in worldwide soybean germplasm collections. Crop Science, 49(3), 903-912.

Jagtap, G. P., Gavate, D. S., and Dey, U. (2012). Control of Colletotrichum truncatum causing anthracnose/pod 
blight of soybean by aqueous leaf extracts, bio-control agents and fungicides. Scientific J. Agriculture, 1(2), 39-52.

Joye, G. F., Berggren, G. T., and Berner, D. K. (1990). Effects of row spacing and within-row plant population on Rhizoctonia aerial blight of soybean and soybean yield. Plant disease, 74(2), 158-160.

Juliatti, F. C., Azevedo, L. A. S., and Cristina, J. (2017). Strategies of chemical protection for controlling soybean rust. Soybean, 35-62.

Khodke, S. W., and Raut, B. T. (2010). Management of root rot/collar rot of soybean. Indian Phytopathology, 63(3), 298-301.

Kittle, D.R., Gray, L.E. (1982) Response of soybeans and soybean pathogens to soil fumigation and foliar fungicide sprays. Plant Dis 66:213-215

Kisan Suvidha (2017) Retrieved from https://www.kisansuvidha.com/soybean -collar-rot/?v=ad4f1670f142

Koch, E., Ebrahimnesbat, F. and Hoppe, H.H. (1983) Light and electron-microscopic studies on the development of soybean rust (Phakopsora pachyrhizi Syd) in susceptible soybean leaves. Phytopathol. Z. 106, 302- 320.

Kolekar, B. U. (2017). Studies on pod blight of soybean in parbhani district (Schw.) (Masters thesis). VasantraoNaik Marathwada Krishi Vidyapeeth, Parbhani.

Kumar, T., Dantre, R. K., and Verma, K. P. (2016). Studies on aerial blight of soybean caused by Rhizoctonia solani kuhn. Journal of Plant Development Sciences Vol, 8(10), 475-482.

Malvick, D. (2018). Rhizoctonia root and stem rot on soybean. Retrieved from https://extension.umn.edu/pestmanagement/rhizoctonia-root-andstem-rot- soybean\#: :text=Rhizoctonia\% 20 root $\%$

20and $\% 20$ stem $\% 20$ rot $\% 20$ is $\% 20 \mathrm{a} \% 20$

common\%20soybean \%20disease,mini

mal\%20effects\%20on\%20plant\%20hea lth

Malvick, D. (2018). Soybean Seed and Seedling Diseases. Retrieved from https://extension.umn.edu/pestmanagement/soybean-seed-andseedling-diseases

Messina, M. J. (1999). Legumes and soybeans: overview of their nutritional profiles and health effects. The American journal of clinical nutrition, 70(3), 439s-450s.

Meyer, W. A., Sinclair, J. B., \&Khare, M. N. (1974). Factors affecting charcoal rot of soybean seedlings. Phytopathology, 64(6), 845-849.

Olutoyosi, O., and Carl, A. (2017). Identification and Characterization of Rhizoctonia Species Associated with Soybean Seedling Disease. Plant disease.

Pestnet. (n.d). Peanut Southern Blight. Retrieved from http://www.pestnet.org/ fact_sheets/peanut_southern_blight_01 1.htm

Prabhu, H. V. (2003). STUDIES ON COLLAR ROT OF SOYBEAN CAUSED BY Sclerotium rolfsiiSacc (Doctoral dissertation, University of Agricultural Science, Dharwad).

Prasad, M., Prasad, M. S., Sharma, V. P., and Kumar, S. (2003). Management of Frog Eye Leaf Spot and Rust Diseases of Soybean in NEB Region. Annals of Plant Protection Sciences, 11(2), 292295.

Rajeswari, B., and Kumari, K. V. S. M. (2009). Bioagents and fungicides for the management of seed and seedling diseases of soybean. Indian Journal of Plant Protection, 37(1/2), 127-131.

Rao, A. S., and Reddy, K. S. (2010). Nutrient management in soybean. The soybean: 
botany, production and uses, 161-190.

Rathore, B.S. (2000) Effect of organic amendments of incidence of seed rot and seedling blight of mothbean. Plant Dis Res 15:217-219.

Rogério, F., Ciampi-Guillardi, M., Barbieri, M. C. G., Bragança, C. A. D., Seixas, C. D. S., Almeida, A. M. R., and Massola Jr, N. S. (2017). Phylogeny and variability of Colletotrichum truncatum associated with soybean anthracnose in Brazil. Journal of applied microbiology, 122(2), 402-415.

Rupe, J., and Sconyers, L. (2008). Soybean rust. The plant health instructor. In Am. Phytopathol. Soc.

Sharma, N.D., and Mehta, S.K. (1996). Soybean rust in Madhya Pradesh. Acta Botanica Indica, 24:115-116.

Sharma, S. K., and Gupta, G. K. (2006). Current status of soybean rust (Phakopsora pachyrhizi)-A Review. Agricultural Reviews, 27(2), 91-102.

Tyler, B. M. (2007). Phytophthora sojae: root rot pathogen of soybean and model oomycete. Molecular plant pathology, $8(1), 1-8$.
Van West, P., Appiah, A. A., and Gow, N. A. (2003). Advances in research on oomycete root pathogens. Physiological and molecular plant pathology, 62(2), 99-113.

Wani, S.H., Sanghera, G.S., Singh, N.B. (2010) Biotechnology and plant disease control-role of RNA interference. Am J Plant Sci 1:55-68.

Wrather, A., Shannon, G., Balardin, R., Carregal, L., Escobar, R., Gupta, G. K., and Tenuta, A. (2010). Effect of diseases on soybean yield in the top eight producing countries in 2006. Plant Health Progress, 11(1), 29.

Yang, X. B., Snow, J. P., and Berggren, G. T. (1990). Analysis of epidemics of Rhizoctonia aerial blight of soybean in Louisiana. Phytopathology, 80(4), 386392.

Zhao, G., Ablett, G. R., Anderson, T. R., Rajcan, I., and Schaafsma, A. W. (2005). Inheritance and genetic mapping of resistance to Rhizoctonia root and hypocotyl rot in soybean. Crop science, 45(4), 1441-1447.

\section{How to cite this article:}

Munmi Borah and Bishakha Deb. 2020. A Review on Symptomatology, Epidemiology and Integrated Management Strategies of Some Economically Important Fungal Diseases of Soybean (Glycine max). Int.J.Curr.Microbiol.App.Sci. 9(11): 1247-1267. doi: https://doi.org/10.20546/ijcmas.2020.911.147 